\title{
Langerhans Cells as Morphologic Mimickers of Atypical Melanocytes on Reflectance Confocal Microscopy: A Case Report and Review of the Literature
}

\author{
Nadiya Chuchvara ${ }^{1}$, Lauren Berger ${ }^{1}$, Catherine Reilly ${ }^{1}$, Amin Maghari² ${ }^{2}$ Babar K. Rao ${ }^{1,3}$
}

1 Center for Dermatology, Rutgers Robert Wood Johnson Medical School, Somerset, New Jersey, US

2 Department of Pathology and Laboratory Medicine, Rutgers Robert Wood Johnson Medical School, New Brunswick, New Jersey, US

3 Department of Dermatology, Weill Cornell Medicine, New York, New York, US

Key words: reflectance confocal microscopy, RCM, Langerhans cells, dendritic cells, atypical cells

Citation: Chuchvara N, Berger L, Reilly C, Maghari A, Rao BK. Langerhans cells as morphologic mimickers of atypical melanocytes on reflectance confocal microscopy: a case report and review of the literature. Dermatol Pract Concept. 2021;11(3):e2021078. DOI: https:// doi.org/10.5826/dpc.1103a78

Accepted: February 2, 2021; Published: May 20, 2021

Copyright: $@ 2021$ Chuchvara et al. This is an open-access article distributed under the terms of the Creative Commons Attribution License BY-NC-4.0, which permits unrestricted noncommercial use, distribution, and reproduction in any medium, provided the original authors and source are credited.

Funding: None.

Competing interests: The authors have no conflicts of interest to disclose.

Authorship: All authors have contributed significantly to this publication.

Corresponding author: Nadiya Chuchvara, BA, Center for Dermatology, Rutgers Robert Wood Johnson Medical School, 1 Worlds Fair Drive, Somerset, NJ 08873, US. Email: nadiyac94@gmail.com

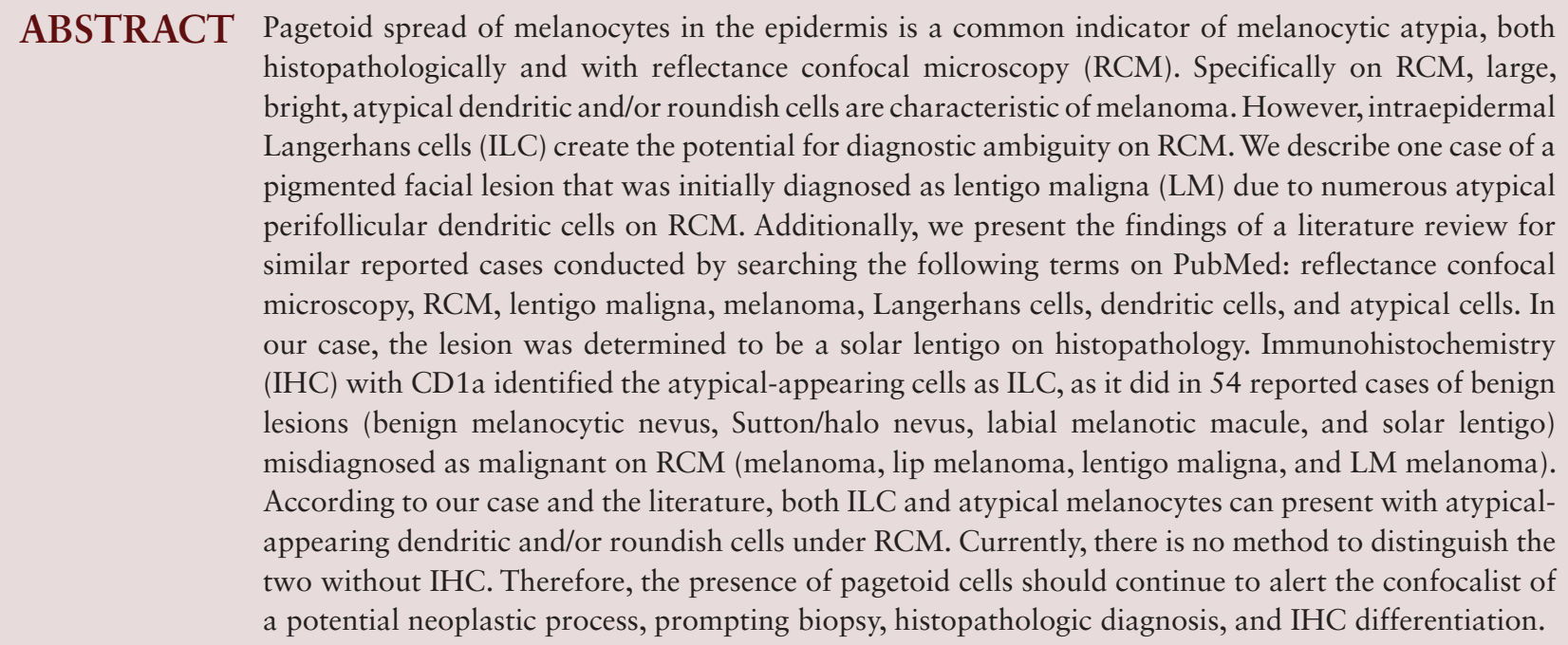




\section{Introduction}

Reflectance confocal microscopy (RCM) is a technique that acquires en face images of the epidermis and papillary dermis in vivo, using a non-invasive laser device (830 nm). Confocal images have a resolution comparable to traditional histopathology [1]. This enables high accuracy diagnosis without the use of biopsy, particularly for pigmented lesions, in which melanin provides strong endogenous contrast [2]. Melanocytic cytologic atypia is suggested by the presence of large (>20 $\mu \mathrm{m}$ ), bright, dendritic, or roundish cells [3]. Pagetoid melanocytosis observed in RCM has been histopathologically correlated to melanoma [4-7]. While not specific for malignancy, the presence of pagetoid spread on RCM of a pigmented lesion carries 11 to $22[7,8]$ times greater risk of melanoma, with odds ratios of 4 to 9 for dendritic cells $[4,6,8]$ and 9.7 to 108 [4-6,8] for roundish cells.

Suspicion for melanoma on RCM increases when atypical cells are densely distributed $\left(>5\right.$ cells $\left./ \mathrm{mm}^{2}\right)$, pleomorphic with large and unusual morphology (triangular, star-shaped),

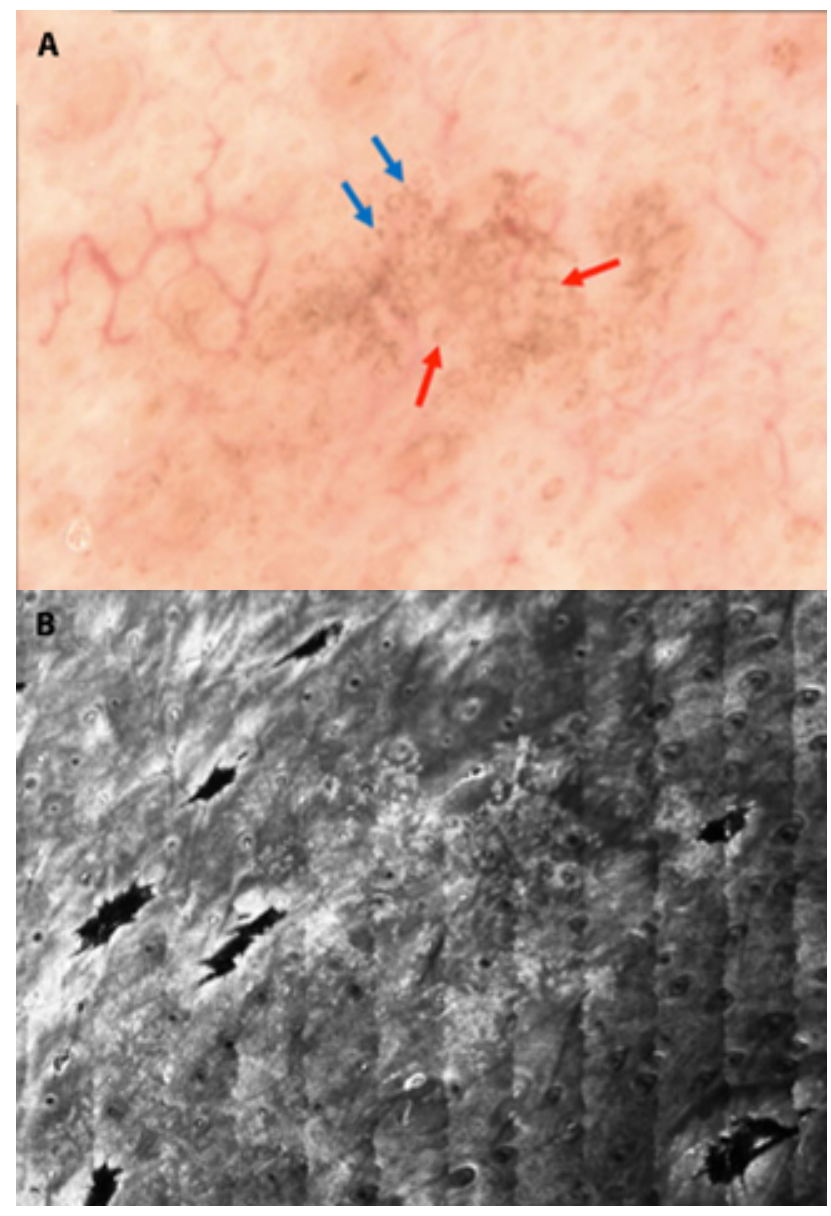

Figure 1. (A) Dermoscopic image of the $5 \mathrm{~mm}$ light brown papule, showing blue-gray granularity (blue arrows) and crescent-shaped perifollicular pigmentation (red arrows). (B) Corresponding RCM mosaic image at the level of the epidermis, acquired using the VivaScope 1500 (Caliber I.D., Rochester, NY) reflectance confocal microscope. roundish, diffuse, and extend to the stratum corneum $[3,5,6]$. Atypical dendritic or roundish pagetoid cells with folliculotropism are characteristic of lentigo maligna (LM) $[9,10]$. We describe a case in which a benign pigmented lesion on the cheek resembled LM on confocal images, owing to dendritic intraepidermal Langerhans cells (ILC) misinterpreted as atypical melanocytes. We present a literature review of additional cases in which the presence of ILC resulted in erroneous diagnosis of melanoma on RCM.

\section{Case Report}

A 64-year-old Caucasian woman presented with a $5 \mathrm{~mm}$ light brown papule on the left cheek that had been present for several months and was growing in size. She had a history of blistering sunburns in childhood and basal cell carcinoma of the right hand 13 years prior to presentation. Family history was significant for ocular melanoma in the patient's mother. Dermoscopic examination of the lesion showed blue-gray granularity and crescent-shaped perifollicular pigmentation, which are considered indicative of melanophages in the dermis and atypical melanocytes extending down hair follicles (Figure 1A) [11,12]. The patient was referred for RCM due to provider suspicion for malignancy and patient preference for a non-invasive procedure (Figure 1B).

RCM revealed an irregular honeycomb pattern with numerous large $(>20 \mu \mathrm{m})$ atypical dendritic pagetoid cells, including some in a perifollicular distribution, consistent with LM (Figure 2). The dermo-epidermal junction (DEJ) contained focal areas of small bright and large bright inflammatory cells (Figure 3).

A shave biopsy was performed, and tissue sections were stained with hematoxylin and eosin (H\&E) (Figure 4A, B). Histopathologic analysis revealed solar lentigo (SL) with underlying sebaceous hyperplasia. Immunohistochemistry (IHC) staining for the melanocyte-specific Melan-A showed a normal distribution of benign-appearing melanocytes in the epidermis, consistent with SL (Figure 4C). Staining for CD1a, a membrane glycoprotein specific for Langerhans

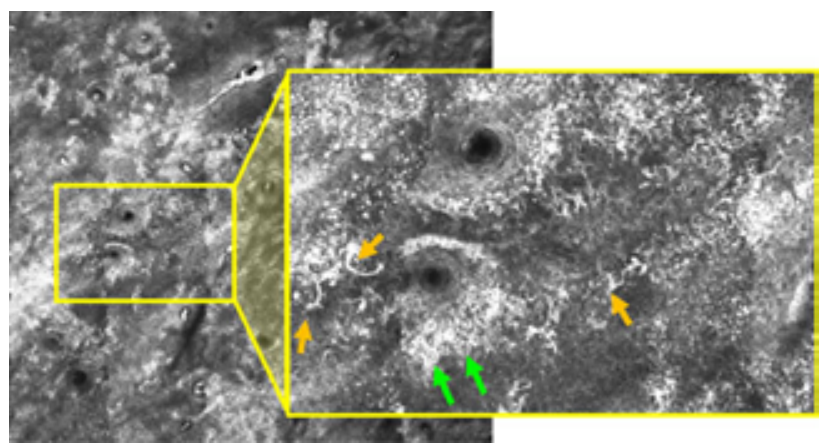

Figure 2. RCM image taken at the level of the epidermis. Inset demonstrates large, atypical pagetoid dendritic cells (orange arrows), with many in a perifollicular distribution (green arrows). 


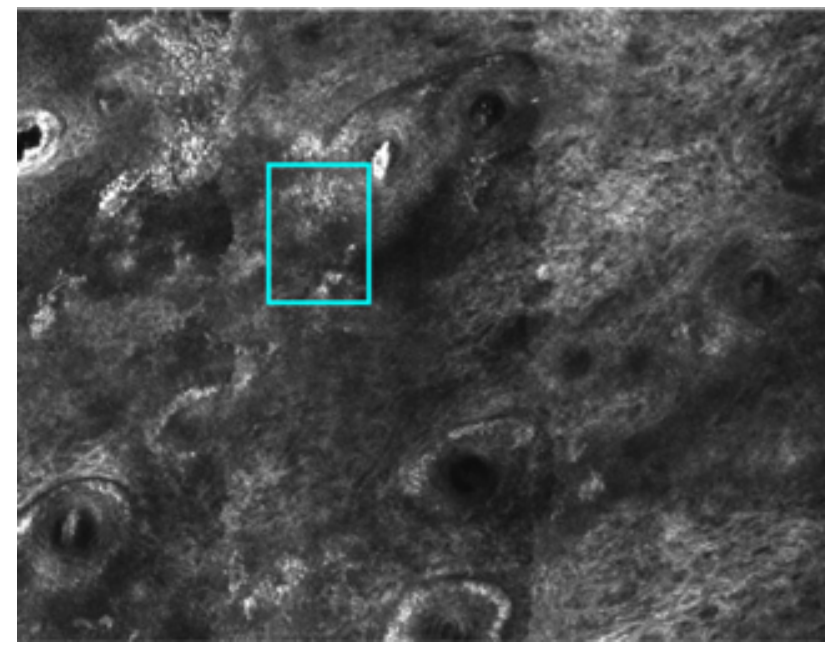

Figure 3. RCM image taken at the level of the DEJ, with focal areas of small bright and large bright inflammatory cells (blue box). cells and immature $\mathrm{T}$ cells, revealed numerous Langerhans cells throughout the epidermis (Figure 4D). Thus, the atypical dendritic cells visualized on RCM likely represented ILC, rather than atypical melanocytes.

\section{Discussion}

RCM is an accurate tool for non-invasive differentiation between benign and malignant melanocytic lesions. For the diagnosis of LM specifically, Guitera et al [10] isolated characteristic RCM features to develop an algorithmic "LM score," resulting in a sensitivity of $85 \%$ and specificity of $76 \%$ for lesions with scores $\geq 2$. Two major features earn +2 points each (nonedged papillae and large round pagetoid cells $>20 \mu \mathrm{m}$ ), three minor features earn +1 point each (three or more atyp-

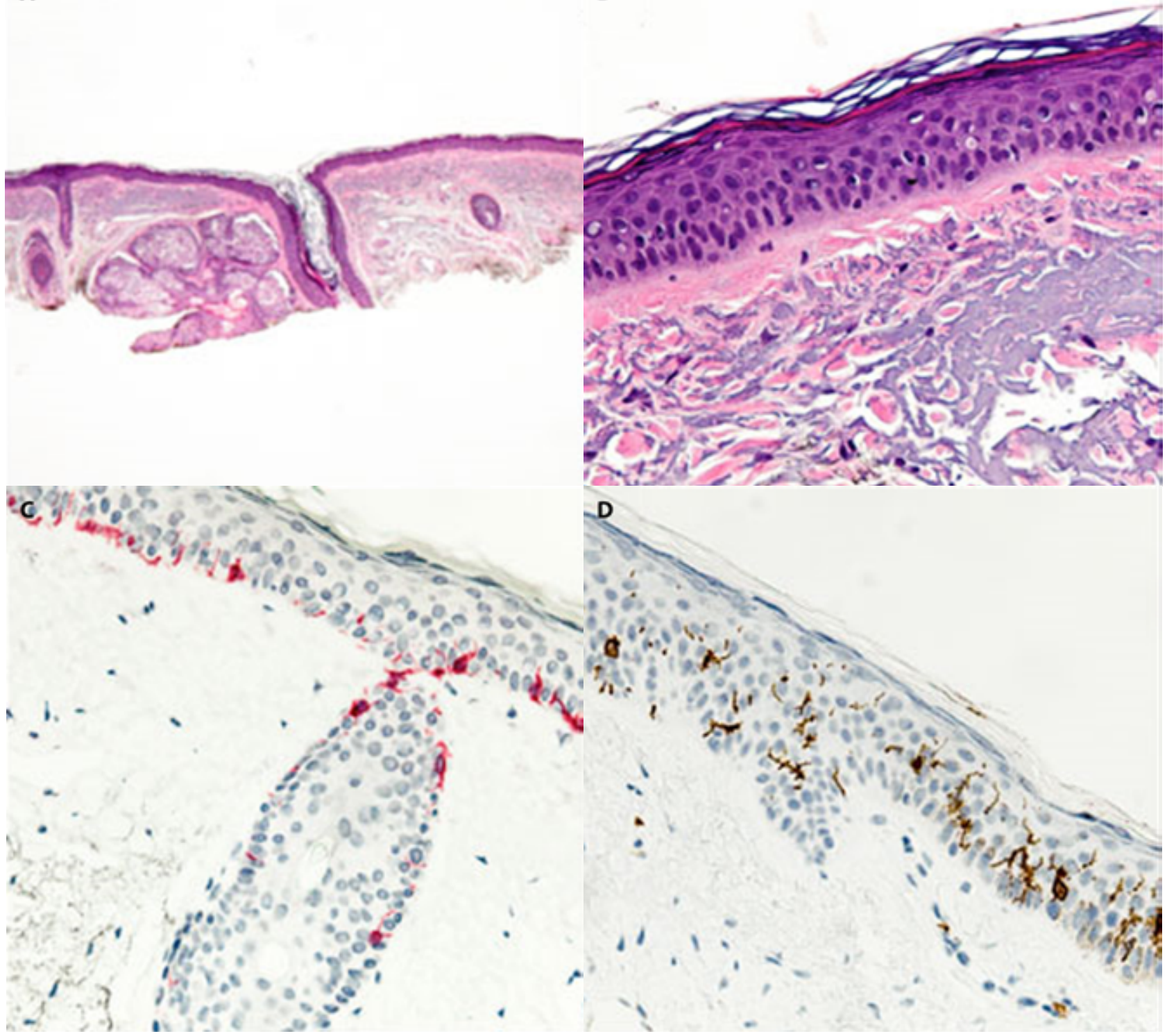

Figure 4. (A) SL with underlying solar elastosis and sebaceous hyperplasia (H\&E, x40). (B) Absence of atypical or dendritic cells with standard H\&E (x200). (C) IHC with Melan-A showing a normal distribution of benign-appearing melanocytes in the epidermis, consistent with SL (x200). (D) IHC with CD1a revealing numerous Langerhans cells throughout the epidermis (x200) 
Table 1. Reported cases of Langerhans cells presenting as atypical melanocytes in benign lesions on RCM.

\begin{tabular}{|c|c|c|c|c|c|}
\hline $\begin{array}{c}\text { RCM } \\
\text { Diagnosis }\end{array}$ & Reference & Case Composition & Clinical Features & $\begin{array}{l}\text { RCM Cytologic } \\
\text { Findings }\end{array}$ & $\begin{array}{c}\text { Histopathologic } \\
\text { Analysis }\end{array}$ \\
\hline \multirow[b]{3}{*}{ Melanoma } & Hashemi et al. ${ }^{14}$ & $\begin{array}{l}24 \text { cases of } \mathrm{BMN} \\
\text { falsely diagnosed as } \\
\text { melanoma }\end{array}$ & $\begin{array}{l}\text { Pigmented lesions } \\
\text { in various locations } \\
\text { including shoulder, } \\
\text { back, abdomen } \\
\text { (others unspecified) }\end{array}$ & $\begin{array}{l}\text { Bright cells in a } \\
\text { pagetoid pattern: } \\
5 / 24 \text { roundish, } 4 / 24 \\
\text { dendritic, } 15 / 24 \\
\text { both }\end{array}$ & $\begin{array}{l}\text { BMN, } \\
\text { CD1a positive, } 7 / 24 \\
\text { Melan-A positive, } \\
\text { cytokeratin- } 20^{+} \\
\text {negative }\end{array}$ \\
\hline & Yelamos et al. ${ }^{18}$ & $\begin{array}{l}1 \text { case of recurrent } \\
\text { nevus falsely } \\
\text { diagnosed as } \\
\text { melanoma }\end{array}$ & $\begin{array}{l}\text { Pigmented macule } \\
\text { on right knee }\end{array}$ & $\begin{array}{l}\text { Pleomorphic, } \\
\text { mostly dendritic } \\
\text { cells throughout the } \\
\text { epidermis, DEJ, and } \\
\text { in the dermal nests }\end{array}$ & $\begin{array}{l}\text { CMN with fibrosis } \\
\text { suggestive of } \\
\text { recurrent nevus; } \\
\text { CD1a positive, } \\
\text { SOX10 normal }\end{array}$ \\
\hline & Brugues et al. ${ }^{19}$ & $\begin{array}{l}21 \text { cases of } \\
\text { clinically atypical } \\
\text { Sutton (halo) } \\
\text { nevi excised due } \\
\text { to possibility of } \\
\text { melanoma }\end{array}$ & $\begin{array}{l}\text { Pigmented macules } \\
\text { with atypical } \\
\text { dermoscopic } \\
\text { features such as: } \\
\text { asymmetrical } \\
\text { peripheral whitish } \\
\text { halo, white/blue- } \\
\text { gray regression, } \\
\text { peppering }\end{array}$ & $\begin{array}{l}\text { 13/21 atypical } \\
\text { pagetoid cells } \\
\text { (dendritic > } \\
\text { roundish); } \\
\text { atypical basal } \\
\text { cells (roundish = } \\
\text { dendritic); } \\
\text { dermal atypical } \\
\text { nucleated cells, } \\
\text { plump cells, and } \\
\text { bright particles }\end{array}$ & $\begin{array}{l}\text { Sutton nevus, CD1a } \\
\text { positive, Melan-A } \\
\text { positive (large } \\
\text { melanocytes) in the } \\
\text { epidermis and DEJ }\end{array}$ \\
\hline $\begin{array}{l}\text { Lip } \\
\text { melanoma }\end{array}$ & Porto et al. ${ }^{20}$ & $\begin{array}{l}3 \text { cases of labial } \\
\text { melanotic macule } \\
\text { falsely diagnosed as } \\
\text { lip melanoma }\end{array}$ & $\begin{array}{l}\text { Pigmented macules } \\
\text { on the lower lip }\end{array}$ & $\begin{array}{l}3 / 3 \text { bright dendritic } \\
\text { cells at the DEJ, } \\
\text { around and between } \\
\text { dermal papillae }\end{array}$ & $\begin{array}{l}\text { Labial melanotic } \\
\text { macule, } \\
\text { CD1a positive, } \\
\text { Melan-A and } \\
\text { S-100 negative }(1 / 3) \\
\text { or normal }(2 / 3)\end{array}$ \\
\hline \multirow[t]{2}{*}{ LM/LMM } & $\begin{array}{l}\text { Gomez-Martin } \\
\text { et al. }{ }^{13}\end{array}$ & $\begin{array}{l}5 \text { cases of } \\
\text { pigmented facial } \\
\text { macules falsely } \\
\text { diagnosed as LM/ } \\
\text { LMM }\end{array}$ & $\begin{array}{l}\text { Clinically } \\
\text { ambiguous } \\
\text { pigmented facial } \\
\text { macules }\end{array}$ & $\begin{array}{l}5 / 5 \text { abundant } \\
\text { dendritic pagetoid } \\
\text { cells; } \\
4 / 5 \text { round, large } \\
\text { pagetoid cells; } 3 / 5 \\
\text { atypical cells at the } \\
\text { DEJ }\end{array}$ & $\begin{array}{l}\text { CD1a positive, } \\
2 / 5 \text { showed both } \\
\text { basal melanocyte } \\
\text { hyperplasia and } \\
\text { ILC secondary to } \\
\text { postradiotherapy } \\
\text { pigmentation }\end{array}$ \\
\hline & Current case & $\begin{array}{l}1 \text { case of SL falsely } \\
\text { diagnosed as LM }\end{array}$ & $\begin{array}{l}\text { Pigmented facial } \\
\text { papule with } \\
\text { dermoscopic } \\
\text { features concerning } \\
\text { for LM }\end{array}$ & $\begin{array}{l}\text { Large, atypical } \\
\text { dendritic } \\
\text { pagetoid cells in } \\
\text { a perifollicular } \\
\text { distribution }\end{array}$ & $\begin{array}{l}\text { SL with underlying } \\
\text { nodular sebaceous } \\
\text { hyperplasia, CD1a } \\
\text { positive, } \\
\text { Melan-A normal }\end{array}$ \\
\hline
\end{tabular}

$\mathrm{BMN}=$ benign melanocytic nevus/nevi; CMN = compound melanocytic nevus; DEJ = dermo-epidermal junction; ILC= intraepidermal Langerhans cell(s); LM = lentigo maligna; LMM - lentigo maligna melanoma; RCM = reflectance confocal microscopy; SL= solar lentigo † marker for Merkel cells

ical cells at the DEJ in five images, follicular localization of atypical cells, and nucleated cells within the papilla), and one minor feature earns -1 point (broadened honeycomb pattern) [10]. Furthermore, Gomez-Martin et al [13] demonstrated the utility of RCM in the diagnosis of ambiguous pigmented facial macules (91.7\% sensitivity and $86.8 \%$ specificity for LM). They found two dermoscopic features (asymmetric follicular pigmentation and target like structures) and two RCM fea- tures (round, large pagetoid cells and follicular localization of atypical cells) to be associated with LM/LMM [13].

In this case, the diagnosis was compromised due to shared morphologic features of Langerhans cells and atypical melanocytes on RCM [14]. Both cell types tend to appear as bright cells in a pagetoid pattern on RCM, often with a dendritic morphology [5]. This explains why intraepidermal dendritic cells can be found in both LM/lentigo maligna melanoma 
(LMM) and benign pigmented facial macules [13]. The bright appearance of Langerhans cells is likely due to their Birbeck granules, which have a high reflection index and thus appear light gray to white under RCM, similar to melanin [14]. Langerhans cells are normally present in the epidermis and serve as antigen-presenting cells for T lymphocytes [15]. Among benign lesions, they are more likely to be prominent around inflammation, such as traumatized benign melanocytic nevi (BMN), recent scars, or lichen planus-like keratosis (LPLK) $[16,17]$. When identified on RCM in high densities, ILC are more likely to result in a false diagnosis of melanoma [14]. While dendritic cells alone are not enough to diagnose LM, as demonstrated by Guitera et al [10] and Gomez-Martin et al [13], the follicular localization of atypical cells on RCM, correlating to asymmetric follicular pigmentation on dermoscopy, raised the level of suspicion for LM in our patient's case.

In the literature, ILC presence has been confirmed in several cases of benign lesions that were perceived to be malignant under RCM. These include suspected cases of melanoma [14,18,19], lip melanoma [20], and LM/LMM [13] (Table 1).

Comparatively high densities of Langerhans cells exist within the head, neck, trunk, and limbs [21], corresponding to the variety of locations reported. Most cases described RCM findings of roundish and dendritic pagetoid cells, although some cases found atypical cells at the DEJ and dermis, as well. As evidenced by our case, traditional H\&E stain was not sufficient in identifying ILC on histopathology and CD1a was required for further classification. In some studies, dendritic pagetoid cells were identified by RCM in lesions that were ultimately benign, but staining for Langerhans cells was not pursued $[10,22,23]$. Thus, the prevalence of ILC in pigmented lesions, and its confounding effect on RCM diagnosis, may be even greater than reported. The inability to use special stains and IHC when conducting in vivo RCM makes such morphologic mimickers indistinguishable across several lesion types.

Some malignant and pre-malignant lesions, particularly pigmented basal cell carcinomas $[17,24]$, in situ or early invasive melanomas [14,25,26], pigmented actinic keratosis [27], and pigmented squamous cell carcinoma (SCC) in situ [28], may also contain a high density of Langerhans cells. In a study classifying melanoma into distinct types, Pellacani et al [29] found that in situ and thin melanomas $(<1 \mathrm{~mm}$ Breslow thickness) were characterized by dendritic cells on RCM. While the authors did not further identify the cells immunohistochemically to rule out the possibility of ILC, this study, and others like it, highlight a possible association of dendritic cells with thin, or early, melanomas. In cases of larger suspicious pigmented lesions, RCM has the added benefit of real-time biopsy guidance, increasing the sensitivity for histopathologic detection of malignancy [10]. Future studies would need to determine whether the identification of dendritic cells on RCM of a clinically ambiguous lesion would result in earlier detection of melanoma.

While atypical cells have been identified as ILC rather than atypical melanocytes across benign lesions including BMN, Sutton (halo) nevi, labial melanotic macules, and SL, the presence of dendritic pagetoid cells should continue to alert the confocalist of a potential neoplastic process, prompting biopsy, histopathologic diagnosis, and IHC differentiation.

\section{References}

1. Edwards SJ, Osei-Assibey G, Patalay R, Wakefield V, Karner C. Diagnostic accuracy of reflectance confocal microscopy using VivaScope for detecting and monitoring skin lesions: a systematic review. Clin Exp Dermatol. 2017;42(3):266-275. DOI: 10.1111/ ced.13055. PMID: 28218469.

2. Rajadhyaksha M, Grossman M, Esterowitz D, Webb RH, Anderson RR. In vivo confocal scanning laser microscopy of human skin: melanin provides strong contrast. J Invest Dermatol. 1995;104(6):946-952. DOI: 10.1111/1523-1747.ep12606215. PMID: 7769264.

3. Pellacani G, Scope A, Gonzalez S, et al. Reflectance confocal microscopy made easy: The 4 must-know key features for the diagnosis of melanoma and nonmelanoma skin cancers. J Am Acad Dermatol. 2019;81(2):520-526. DOI: 10.1016/j. jaad.2019.03.085. PMID: 30954581.

4. Pellacani G, Guitera P, Longo C, Avramidis M, Seidenari S, Menzies S. The impact of in vivo reflectance confocal microscopy for the diagnostic accuracy of melanoma and equivocal melanocytic lesions. J Invest Dermatol. 2007;127(12):2759-2765. DOI: 10.1038/sj.jid.5700993. PMID: 17657243.

5. Pellacani G, Cesinaro AM, Seidenari S. Reflectance-mode confocal microscopy for the in vivo characterization of pagetoid melanocytosis in melanomas and nevi. J Invest Dermatol. 2005;125(3):532537. DOI: 10.1111/j.0022-202X.2005.23813.x. PMID: 16117795.

6. Pellacani G, Cesinaro AM, Seidenari S. Reflectance-mode confocal microscopy of pigmented skin lesions--improvement in melanoma diagnostic specificity. J Am Acad Dermatol. 2005;53(6):979-985. DOI: 10.1016/j.jaad.2005.08.022. PMID: 16310058.

7. Segura S, Puig S, Carrera C, Palou J, Malvehy J. Development of a two-step method for the diagnosis of melanoma by reflectance confocal microscopy. J Am Acad Dermatol. 2009;61(2):216-229. DOI: 10.1016/j.jaad.2009.02.014. PMID: 19406506.

8. Guitera P, Menzies SW, Longo C, Cesinaro AM, Scolyer RA, Pellacani G. In vivo confocal microscopy for diagnosis of melanoma and basal cell carcinoma using a two-step method: analysis of 710 consecutive clinically equivocal cases. J Invest Dermatol. 2012;132(10):2386-2394. DOI: 10.1038/jid.2012.172. PMID: 22718115.

9. Gamo R, Pampin A, Floristan U. Reflectance confocal microscopy in lentigo maligna. Actas Dermosifiliogr. 2016;107(10):830-835. DOI: 10.1016/j.ad.2016.07.012. PMID: 27614735.

10. Guitera P, Pellacani G, Crotty KA, et al. The impact of in vivo reflectance confocal microscopy on the diagnostic accuracy of lentigo maligna and equivocal pigmented and nonpigmented macules of the face. J Invest Dermatol. 2010;130(8):2080-2091. DOI: 10.1038/jid.2010.84. PMID: 20393481. 
11. Braun RP, Gaide O, Oliviero M, et al. The significance of multiple blue-grey dots (granularity) for the dermoscopic diagnosis of melanoma. Br J Dermatol. 2007;157(5):907-913. DOI: 10.1111/j.1365-2133.2007.08145.x. PMID: 17725673.

12. Langley RG, Burton E, Walsh N, Propperova I, Murray SJ. In vivo confocal scanning laser microscopy of benign lentigines: comparison to conventional histology and in vivo characteristics of lentigo maligna. J Am Acad Dermatol. 2006;55(1):88-97. DOI: 10.1016/j.jaad.2006.03.009. PMID: 16781299.

13. Gomez-Martin I, Moreno S, Andrades-Lopez E, et al. Histopathologic and immunohistochemical correlates of confocal descriptors in pigmented facial macules on photodamaged skin. JAMA Dermatol. 2017;153(8):771-780. DOI: 10.1001/jamadermatol.2017.1323. PMID: 28564685.

14. Hashemi P, Pulitzer MP, Scope A, Kovalyshyn I, Halpern AC, Marghoob AA. Langerhans cells and melanocytes share similar morphologic features under in vivo reflectance confocal microscopy: a challenge for melanoma diagnosis. J Am Acad Dermatol. 2012;66(3):452-462. DOI: 10.1016/j.jaad.2011.02.033. PMID: 21798622 PMCid:PMC3264757.

15. Breathnach SM. The Langerhans cell. Br J Dermatol. 1988;119(4):463-469. DOI: 10.1111/j.1365-2133.1988. tb03249.x. PMID: 3056492.

16. Bassoli S, Rabinovitz HS, Pellacani G, et al. Reflectance confocal microscopy criteria of lichen planus-like keratosis. J Eur Acad Dermatol Venereol. 2012;26(5):578-590. DOI: 10.1111/j.14683083.2011.04121.x. PMID: 21605173.

17. Segura S, Puig S, Carrera C, Palou J, Malvehy J. Dendritic cells in pigmented basal cell carcinoma: a relevant finding by reflectance-mode confocal microscopy. Arch Dermatol. 2007;143(7):883-886. DOI: 10.1001/archderm.143.7.883. PMID: 17638732 .

18. Yelamos O, Jain M, Busam KJ, Marghoob AA. Recurrent nevus as a pitfall of melanoma diagnosis under reflectance confocal microscopy. Australas J Dermatol. 2018;59(3):227-229. DOI: 10.1111/ajd.12733. PMID: 28990158.

19. Brugues A, Ribero S, Martins da Silva V, et al. Sutton Naevi as Melanoma Simulators: Can Confocal Microscopy Help in the Diagnosis? Acta Derm Venereol. 2020;100(10):adv00134. DOI: 10.2340/00015555-3488. PMID: 32318743

20. Porto AC, Fraga-Braghiroli N, Blumetti TP, et al. Reflectance confocal microscopy features of labial melanotic macule: Report of three cases. JAAD Case Rep. 2018;4(10):1000-1003. DOI: 10.1016/j.jdcr.2018.07.019. PMID: 30417063.
21. Modlin RL, Miller LS, Bangert C, Stingl G. Innate and adaptive immunity in the skin. In: Goldsmith LA, Katz SI, Gilchrest BA, Paller AS, Leffell DJ, Wolff K, eds. Fitzpatrick's Dermatology in General Medicine, 8e. New York, NY: The McGraw-Hill Companies; 2012.

22. Uribe P, Collgros H, Scolyer RA, Menzies SW, Guitera P. In vivo reflectance confocal microscopy for the diagnosis of melanoma and melanotic macules of the lip. JAMA Dermatol. 2017;153(9):882-891. DOI: 10.1001/jamadermatol.2017.0504. PMID: 28467525 PMCid:PMC5710424.

23. Menge TD, Hibler BP, Cordova MA, Nehal KS, Rossi AM. Concordance of handheld reflectance confocal microscopy (RCM) with histopathology in the diagnosis of lentigo maligna (LM): A prospective study. J Am Acad Dermatol. 2016;74(6):1114-1120. DOI: 10.1016/j.jaad.2015.12.045. PMID: 26826051.

24. Agero AL, Busam KJ, Benvenuto-Andrade C, et al. Reflectance confocal microscopy of pigmented basal cell carcinoma. J Am Acad Dermatol. 2006;54(4):638-643. DOI: 10.1016/j. jaad.2005.11.1096. PMID: 16546585.

25. Toriyama K, Wen DR, Paul E, Cochran AJ. Variations in the distribution, frequency, and phenotype of Langerhans cells during the evolution of malignant melanoma of the skin. J Invest Dermatol. 1993;100(3):269S-273S. DOI: 10.1111/1523-1747.ep12470135. PMID: 7680054

26. Stene MA, Babajanians M, Bhuta S, Cochran AJ. Quantitative alterations in cutaneous Langerhans cells during the evolution of malignant melanoma of the skin. J Invest Dermatol. 1988;91(2):125-128DOI: 10.1111/1523-1747.ep12464142. PMID: 3260930.

27. Ulrich M, Krueger-Corcoran D, Roewert-Huber J, Sterry W, Stockfleth E, Astner S. Reflectance confocal microscopy for noninvasive monitoring of therapy and detection of subclinical actinic keratoses. Dermatology. 2010;220(1):15-24. DOI: 10.1159/000254893. PMID: 19907131.

28. Shahriari N, Grant-Kels JM, Rabinovitz HS, Oliviero M, Scope A. Reflectance confocal microscopy criteria of pigmented squamous cell carcinoma in situ. Am J Dermatopathol. 2018;40(3):173-179. DOI: 10.1097/DAD.0000000000000938. PMID: 28816741.

29. Pellacani G, De Pace B, Reggiani C, et al. Distinct melanoma types based on reflectance confocal microscopy. Exp Dermatol. 2014;23(6):414-418. DOI: 10.1111/exd.12417. PMID: 24750486. 